\title{
Achtergronden bij de Richtlijn bekwaamverklaringen in de specialistenopleiding
}

\section{Status van de Richtlijn}

De voorliggende Richtlijn betreft de verklaring van bekwaamheid voor deelaspecten van een medisch specialisme. Bekwaamverklaringen vormen een logische operationalisatie van competenties die zijn voorgeschreven. In het kaderbesluit Centraal College Medische Specialismen (CCMS) van 11 mei 2009 zijn de volgende passages opgenomen:

'De specialismegebonden competenties zijn door de wetenschappelijke vereniging opgesteld en herkenbaar in het opleidingsplan verwerkt. Vereist wordt dat de specialismegebonden competenties moeten worden behaald op de bijbehorende beheersingsniveaus (ook wel: bekwaamheidsniveaus. Het opleidingsplan bevat tenminste de specialismegebonden competenties met bijbehorende bekwaamheidniveaus).'3)

Het in deze passage bedoelde 'behalen op bekwaamheidsniveau' vormt de basis voor deze Richtlijn. De Richtlijn beoogt aanwijzingen te geven voor de invoering en toepassing van bekwaamverklaringen in de medische vervolgopleiding. De Richtlijn heeft geen kracht van wet, maar wordt wel aanbevolen bij de vormgeving van opleidingen.

\section{Wat is een bekwaamverklaring?}

Een verklaring van bekwaamheid voor de uitoefening van een medisch specialistisch beroep kan worden beschouwd als de formele vaststelling of erkenning van deze bekwaamheid. De opname in een specialistenregister is een formele verklaring voor de opleiding als geheel.

In deze Richtlijn wordt met bekwaamverklaringen echter niet gedoeld op deze algemene erkenning als medisch specialist, maar op de erkenning van een behaald competentieniveau dat zelfstandige uitoefening van een deelaspect van het specialistische vakgebied mogelijk maakt tijdens de opleiding en wel vóórdat registratie heeft plaatsgevonden.

Deze bekwaamverklaringen hebben in de geneeskunde geen juridische status, maar wel een praktische betekenis en vormen in beginsel een formalisering van de toestemming die aios in iedere opleiding soms welbewust maar vaak impliciet wordt gegeven om bepaalde, professionele activiteiten zelfstandig uit te voeren. Deze formalisering impliceert een meer algemene erkenning van het behaalde competentieniveau dan alleen een erkenning door de supervisor. Bekwaamverklaringen zijn onderdeel van het attainments-portfolio (het onderdeel van het portfolio waarin de verworven bekwaamheden zijn weergegeven) van de aios. Aios die bekwaamverklaard zijn voor een bepaalde professio-

3) CCMS concept Kaderbesluit betreffende de algemene eisen voor de opleiding, registratie en herregistratie van medisch specialisten en profielartsen en voor de erkenning van opleiders, plaatsvervangend opleiders en opleidingsinrichtingen. Versie 11 mei 2009, (hoofdstuk B, paragraaf B2 en B3). 
nele activiteit hebben niet alleen een erkenning gekregen van een behaald kennis- en vaardigheidsniveau, maar hebben daarmee ook een verantwoordelijkheid om deze activiteit op dit niveau uit te voeren.

Er is echter een belangrijke connotatie bij de bekwaamverklaring die wel raakt aan de juridische context. Immers, in de wet Beroepen Individuele Gezondheidszorg (BIG) is de idee van 'bevoegd mits bekwaam' een grondslag voor het functioneren van de professionals in de zorg. Bevoegdheid bestaat dus bij de gratie van bekwaamheid, juridisch gesproken dus ongeacht diploma's van opleidingen. Bekwaamheid moet echter worden vastgesteld door hiërarchisch leidinggevenden; dat kan een afdelingshoofd of soms een ziekenhuisbestuur zijn. In de opleiding is dat de opleider. In feite is hier steeds sprake van bekwaamverklaring. Tot nu toe is deze bekwaamverklaring in veel gevallen zeer informeel. Slechts het artsdiploma en de inschrijving in een specialistenregister impliceren een veronderstelde bekwaamheid. Het werken met bekwaamverklaringen zoals bedoeld in deze Richtlijn geeft een meer solide basis aan de uitvoering van de wet BIG.

Het woord 'bekwaam' heeft hierbij dus een zelfde connotatie als 'competent', namelijk die van 'bevoegd'. De aios die 'bekwaam' verklaard wordt, volgens de betekenis die in deze Richtlijn wordt gehanteerd, is zowel 'kundig', als 'geschikt' als 'bevoegd' voor de uitvoering van de professionele activiteit waarop de verklaring van toepassing is. Dat betekent niet dat er niets meer mis kan gaan. Een bekwaamverklaring is als een rijbewijs. Er is een minimaal competentieniveau geconstateerd, op grond waarvan het vertrouwen wordt uitgesproken dat de persoon voldoende veilig zal deelnemen aan het verkeer en dat zelfstandig kan doen. Echte ervarenheid en kundigheid volgen pas lang daarna. Een rijbewijs noch een grote rijervaring garanderen niet dat er geen fouten en ongelukken zullen optreden.

\section{Het doel van bekwaamverklaringen}

Bekwaamverklaringen vormen een logisch onderdeel van het competentiegericht opleiden, omdat hiermee bereikte competenties zichtbaar worden gemaakt. Het is van belang om de aios de diverse taken op de klinische werkvloer stapsgewijs, en afhankelijk van de resultaten van het leerproces, in de loop van de opleiding steeds meer zelfstandig toe te vertrouwen. $^{2}$

Met het afgeven van bekwaamverklaringen, als afronding van deze groei naar zelfstandigheid, worden drie doelen beoogd:

- Het sturen van het leerproces van de aios en het doelgericht opleiden: De bekwaamverklaringen worden afgegeven op het moment dat de opleider de aios zodanig deskundig en bekwaam beoordeelt ten aanzien van de specifieke professionele activiteit, dat deze handeling hem of haar zonder directe supervisie kan worden toevertrouwd. De aios en de opleider zullen erop toezien dat de activiteit binnen de in het opleidingsplan gestelde periode wordt geleerd. Bekwaamverklaringen sturen het leerproces, omdat ze voor de aios een zeer concreet, tastbaar doel zijn, en daarmee een ontwikkelingsmotief vormen.

- Het objectiveren van de toenemende bekwaamheid van de aios: Binnen een opleidingstraject geeft het samenvattende bekwaamverklaringsformulier in één oogopslag de verworven en nog te verwerven bekwaamheden van de aios weer. Dit maakt de bereikte staat van opleiding duidelijk, zowel voor de aios zelf als voor de leden van het opleidingsteam, en ook als er sprake is van 
een verandering van opleidingskliniek. Bekwaamverklaringen vormen de operationalisatie van het competentiegericht opleiden. Hiermee wordt aan de hand van concrete activiteiten duidelijk welke competenties zijn bereikt.

In het curriculum HOOG Herziening Opleiding Obstetie en Gynaecologie worden drie ijkpunten gedefinieerd in de opleiding tot gynaecoloog die een minimumniveau beschrijven voor de bekwaamheid op diverse thema's na twee, vier en zes jaar. Ook in opleidingsplannen van andere specialistenopleidingen (bijvoorbeeld Structuur Curriculum Heelkunde voor Reflectieve Professionals - SCHERP - van de Heelkunde en Herziening Opleiding Radiologie - HORA - van de Radiologie) zijn dergelijke afspraken verwoord over de 'output' van een deel van de opleiding. Zowel een aios met een snelle en een aios met een vertraagde ontwikkeling komen op deze manier duidelijk in beeld. Bij een vertraging zal een proces van remediering met bindende afspraken over voorwaarden voor continuering van de opleiding wenselijk zijn.

- Aandacht voor borgen en verantwoorden van de patiëntveiligheid: De kwaliteit van de patiëntenzorg vereist dat het inzichtelijk is voor welke handelingen zorgverleners gekwalificeerd zijn. Dat is mogelijk met bekwaamverklaringen. Het werken met bekwaamverklaringen zal naar verwachting invloed hebben op de patiëntveiligheid, omdat veel scherper gedefinieerd is welke aios welke handelingen met welke mate van supervisie kan uitvoeren. De bekwaamverklaring zal alleen terecht zijn wanneer de professionele rijping van een niveau is, waarop de aios situaties met valkuilen en risico's herkent en op basis daarvan selectief supervisie inroept. Deze situaties zijn afhankelijk van de te behande- len casus, maar ook van de context, zoals de beschikbare infrastructuur en het team waarin gewerkt wordt. Overigens is ook na bekwaamverklaring de aios nog steeds in opleiding en de supervisor eindverantwoordelijk.

\section{Achtergronden en argumenten voor de introductie van bekwaam- verklaringen in de medisch- specialistische opleiding}

\section{A. Maatschappelijke argumenten}

Traditioneel is er in de medisch-specialistische vervolgopleiding sprake van een leerling-gezel/meester verhouding. De leerlingrol wordt vervuld door de student of coassistent, de gezel is de aios en de meester is het ervaren klinische staflid of de opleider. Lange tijd was er, onderwijskundig gesproken, in deze opleidingsfase niet veel meer dan dat. ${ }^{3}$ Meester en gezel werkten intensief en exclusief samen, waardoor de meester te allen tijde op de hoogte was van het actuele vaardigheidsniveau van zijn gezel. Er werd geen noodzaak gevoeld voor formele toetsing en de mate van zelfstandigheid die toevertrouwd werd aan de gezel werd door de meester min of meer intuïtief bepaald. ${ }^{4}$

Over de afgelopen tientallen jaren hebben zich meerdere veranderingen voltrokken in het opleidingsklimaat van de medische vervolgopleidingen, waardoor het opleiden volgens uitsluitend het meestergezel principe niet langer mogelijk is. Het meester-gezel model verdient een betere inbedding. De toename van het aantal aios en de reductie van de werkuren van de aios leiden ertoe dat per aios minder verrichtingen voor handen zijn en dat de leermomenten gericht benut moeten worden. De onder de medisch specialisten zichtbare trend naar parttime werken en de verregaande subspecialisatie zorgen er voor dat de aios tegenwoordig niet één 
maar meerdere meesters heeft. Elke specialist in een opleidingskliniek is ook bij de opleiding van meerdere aios op hetzelfde moment betrokken. Menig superviserend specialist heeft slechts beperkt zicht op de bekwaamheid van zijn aios. ${ }^{5}$ Samen met de zich uitbreidende claimcultuur heeft dit ertoe geleid dat specialisten in opleidingsklinieken minder geneigd zijn hun aios de zelfstandigheid te geven waar ze qua ervaring en niveau aan toe zijn. ${ }^{6}$ Onder de aios heeft dit tot bezorgdheid geleid en de vraag opgeroepen of ze aan het eind van hun specialistenopleiding wel voldoende zijn voorbereid op een zelfstandige praktijkvoering. ${ }^{7-8}$ Het is aannemelijk dat bekwaamverklaringen en de gelegenheid tot zelfstandig werken helpen om de aios voor te bereiden op het zelfstandig praktijk voeren als medisch specialist. Ook landen die een sterkere claimcultuur kennen dan Nederland erkennen dit en hebben hieromtrent verklaringen opgenomen in recente richtlijnen over het opleiden van medisch specialisten. ${ }^{9-10}$

Tegelijkertijd is er in de maatschappij, zowel bij patiënten als bij regelgevende instanties, behoefte ontstaan aan transparantie en aan een toetsbare opstelling van medische professionals. ${ }^{11-12}$ De neiging tot subspecialisatie, het werken met verschillende zorgprofessionals op een zelfde domein en de in de praktijk waarneembare behoefte om gedurende een loopbaan een ontwikkelingsgang te maken langs meerdere domeinen, passen bij uitstek bij het werken met een formeel vastgestelde bekwaamheid op diverse terreinen. Bekwaamheid op deelterreinen kan zich uitstrekken over de grenzen van een specialisme. Een zorgvuldige keuze van deelterreinen opent juist weer mogelijkheden voor het meer gericht opleiden van bijvoorbeeld nurse practitioners en physician assistants. Bekwaamheid in een spe- cialisatie houdt enerzijds een bekwaamheid in op een kerndomein dat voor alle specialisten van dat specialisme geldt en anderzijds een bekwaamheid op domeinen die passen bij een differentiatie of een subspecialisatie. Bekwaamheid moet onderhouden worden. Accreditatieorganen buigen zich decentraal en centraal over de vraag hoe bekwaamheid in stand gehouden kan worden.

Bekwaamverklaringen, die aangeven dat een aios formeel getoetst is en dat hij/zij heeft laten zien dat een behandeling voldoende wordt beheerst om deze zelfstandig te kunnen uitvoeren, vormen een essentieel onderdeel van effectieve samenwerking in het zorgteam, en bevorderen het doelmatig gebruik van de opleidingsinfrastructuur. Het maakt voor alle betrokkenen (superviserend specialist, aios, verpleging en patiënt) duidelijk wat een aios zelfstandig kan en mag doen. Hiermee wordt voorkomen dat een aios boven zijn competentieniveau werkt. Het geeft de superviserend specialist houvast in het bepalen van de mate van zelfstandigheid die hij aan een aios toevertrouwt. ${ }^{13} 14$ De mate van zelfstandigheid van de aios bij het uitoefenen van bepaalde taken is medebepalend voor het functioneren van het team waarvan de aios deel uitmaakt en voor de vorm van de organisatie rond de uitvoering van die taken. Een minder ervaren aios dient meer aandacht en back-up gedrag van alle leden van het team te krijgen rondom de uitvoering van diens taak. De organisatie moet bijvoorbeeld rekening houden met een langere tijd die nodig is voor de uitvoering van bepaalde activiteiten. Bekwaamverklaringen geven duidelijkheid over de mate van zelfstandigheid van aios en dragen zo dus bij aan een doelmatiger organisatie van zorg en opleiding.

Naast een roep om doelmatigheid bij de - zeer kostbare - opleiding tot specialist is 
er ook de vraag naar een flexibele opleidingsduur. Een goed werkend systeem van bekwaamverklaringen brengt meer structuur in deze discussie. Als transparant is waartoe de individuele aios bekwaam verklaard is dan komt het mo-ment waarop aan de criteria voor de titel specialist is voldaan niet voor iedereen tegelijkertijd. Er zullen snelle en trage aios zijn.

\section{B. Onderwijskundige argumenten}

Er is een groot verschil tussen de gevoelde verantwoordelijkheid bij het werken onder directe supervisie en bij het zelfstandig werken. In het laatste geval moeten beslissingen geheel zelfstandig genomen worden en is men ook verantwoordelijk voor de consequenties van de genomen beslissingen. Het is bekend dat enige spanning, soms 'constructieve frictie' genoemd, tussen wat een aios onder gecontroleerde omstandigheden al kan en wat hij of zij nog niet kan - het streefniveau, een zeer goede stimulus vormt om vaardigheden op het gewenste niveau te brengen. ${ }^{15-16}$

Daarnaast is de 'self-efficacy' van een aios, waarmee bedoeld wordt dat een aios zichzelf in staat acht een verrichting zelfstandig uit te voeren, belangrijk voor het functioneren van de aios. Self-efficacy wordt onder meer gestimuleerd door eerdere succeservaringen en door positieve reacties van de directe omgeving; in dit geval van de superviserende specialist. ${ }^{17}$ Startende specialisten worden geconfronteerd met grote veranderingen in hun werk- en levensstijl. ${ }^{18}$ Het werken onder supervisie maakt plaats voor het werk als supervisor. Tevens komen andere dan medisch-inhoudelijke werkzaamheden meer op de voorgrond te staan. ${ }^{19} \mathrm{Er}$ is een onderscheid tussen wat als 'transition' en wat als 'change' is beschreven. ${ }^{20} 21$ 'Change' is een externe verandering van werk en omgeving en met 'transition' wordt het innerlijke proces van verandering bedoeld. Naarmate de verandering in werkzaamheden groter zal zijn bij aanvang van de betrekking als specialist, zal deze transitie meer van de persoon vragen. ${ }^{22}$ Indien de aios reeds in de opleiding als 'zelfstandige' heeft gefunctioneerd zal de 'change' minder groot zijn en minder stress met zich meebrengen. Gespreide bekwaamverklaringen kunnen helpen om de aios op bepaalde terreinen reeds in de opleiding bepaalde verantwoordelijkheden te geven zodat de transitie naar het specialistische beroep verkleind wordt.

Het concept van bekwaamverklaringen past ook bij uitstek bij het competentiegericht opleiden. Carraccio heeft gewezen op de consequentie van competentiegerichte specialistenopleidingen voor de ontwikkelingsstadia van de aios. Zij vergelijkt deze ontwikkeling met de stadia van het Dreyfus \& Dreyfus model: 1) novice, 2) advanced beginner, 3) competent, 4) proficient, 5) expert en voegt 6) 'master' daaraan toe. ${ }^{23-25}$ 'Competent' vormt in deze reeks het stadium waarop erkenning in de vorm van een bekwaamverklaring passend is.

\section{De keuze van onderwerpen voor een bekwaamverklaring}

De activiteiten waarvoor bekwaamverklaringen worden afgegeven betreffen concrete handelingen die onderdeel vormen van het beroep en waarvan zich de vraag kan voordoen of deze 'kan worden toevertrouwd aan een voldoende competente aios'. Deze worden wel Entrustable Professional Activities (EPA's) genoemd. ${ }^{2} 13$

Het is niet nodig en niet wenselijk om voor alle door de aios te leren elementen in het basispakket van de betreffende discipline bekwaamverklaringen te maken. Sommige activiteiten behoeven geen bekwaamverklaring. Bij de curriculumopbouw in de Nederlandse vervolgoplei- 
dingen zijn twee manieren gekozen om met bekwaamverklaringen om te gaan. Bij de eerste methode wordt uitgegaan van afzonderlijke taken van een beperkte omvang. Criteria bij de keuze van deze taken zijn vooral de frequentie van voorkomen (bijvoorbeeld de bevalling), een prototype van een behandeling waarbij enkele algemene competenties opvallend worden aangesproken (bijvoorbeeld triage op de verloskamers) en behandelingen met een hoger risico (bijvoorbeeld de zorg rond de sectio caesarea). Per taak wordt de aios bekwaam verklaard. Een tweede methode is bekwaamverklaring voor een heel thema. Als voor meerdere taken van beperkte omvang binnen een vakinhoudelijk thema een hoger niveau van bekwaamheid bestaat, kan onder voorwaarden (zie onder 6) bekwaamheid voor het hele thema worden toegekend (bijvoorbeeld thema 'de gecompliceerde bevalling').

De concilia van de verschillende wetenschappelijke verenigingen kiezen binnen het betreffende specialisme de EPA's en thema's waarvoor bekwaamverklaringen zinvol zijn en geven aan welke bekwaamverklaringen in welke fasen van de opleiding verworven moeten worden.

\section{Gronden voor een valide bekwaamverklaring in de praktijk}

De beoordeling van de algemene bekwaamheid van de medisch specialist is buitengewoon lastig en duidelijk is dat voor een valide en betrouwbaar oordeel een samenstel van beoordelingsinstrumenten nodig is, zoals examens, KPB scores en kwaliteitsindicatoren, ontleend aan patiëntenstatussen. ${ }^{26}$ Lurie et al. constateren in een recent literatuurreview dat competenties van het Accreditation Council for Graduate Medical Education (ACGME) model niet afzonderlijk toetsbaar zijn; datzelfde geldt ongetwijfeld evenzeer voor de CanMEDS competenties. ${ }^{27}$ Een beoordeling van professionele activiteiten die verschillende competenties in zich verenigen is daarom beter dan de beoordeling van afzonderlijke competenties als deze los staan van concrete klinische activiteiten. Een bespreking van methoden voor de beoordeling hiervan valt buiten het bestek van deze Richtlijn. Epstein geeft een courant overzicht van methoden. ${ }^{28}$ Wat daarover in dit bestek gezegd kan worden is dat observatie in de klinische praktijk (het 'does' niveau van Miller) essentieel is. ${ }^{29}$

Hoe vindt de opbouw van de bekwaamverklaring in onze praktijk nu plaats? In een opleidingscurriculum als HOOG is dat in grote lijnen terug te vinden. ${ }^{30}$ In het portfolio worden een aantal parameters vergaard. De ervaring (aantallen en variaties), de toetsing van kennis en vaardigheden via schriftelijke en mondelinge kennistoetsing, de toetsing van vaardigheden in een simulatieomgeving, de toetsing bij directe observatie op de werkvloer en de 360 graden beoordelingen door teamleden, vormen de ingrediënten van het portfolio. Het portfolio wordt periodiek, in samenhang met het door de aios zelf gepercipieerde niveau van zelfstandigheid op diverse terreinen, besproken in de opleidingsgroep. Binnen de professie is er enige mate van 'authority based' consensus over de mate van kennis, vaardigheid en ervaring die nodig is om een professionele activiteit te beheersen. Omdat er vaak impliciet werd gewerkt naar de fase van zelfstandigheid is de overgang naar explicitering relatief ingewikkeld. Het proces waarbij de portfolioparameters leiden tot bekwaamverklaring is vaak niet strak gedefinieerd. In het gynaecologencurriculum HOOG is in grote lijnen terug te vinden welke kennis, vaardigheid en ervaring enerzijds en welke toetsing anderzijds de basis moeten zijn voor de 
besluiten die de opleidingsgroep neemt. Een onopgeloste discussie is de vraag wat zwaarder moeten wegen bij een bekwaamverklaring: het aantal keren dat de aios een bepaalde professionele activiteit zonder bijzondere observatie heeft volbracht of juist de specifieke beoordelingen van zijn of haar handelen in de praktijk? Bovendien zijn thans de beoordelingen in de praktijk meestal ontwikkelingsgericht ingestoken. Voor een bekwaamverklaring zouden opleider en aios een meer summatieve praktijkbeoordeling kunnen afspreken, waarbij goed op alle aspecten wordt gelet. Het zou een goede zaak zijn om bij elke praktijkbeoordeling op het beoordelingsformulier in te vullen op welk niveau de aios deze behandeling uitvoerde, c.q. zou kunnen uitvoeren: niveau 2 (strenge supervisie), niveau 3 (beperkte supervisie), niveau 4 (zonder supervisie) en niveau 5 (superviseert zelf en geeft onderwijs). Dit dwingt de supervisor en de aios telkenmale na te denken over de vraag op welk niveau de aios functioneert en helpt met het toewerken naar zelfstandigheid en het vastleggen van de bereikte bekwaamheid. Een te voren afgesproken aantal beoordelingen (bijvoorbeeld vijf) op niveau 4 kan als voorwaarde gelden om een bekwaamverklaring op niveau 4 in overweging te nemen. Vijf korte observaties zijn in de regel te weinig voor een psychometrisch verantwoorde beslissing over bekwaamheid, maar hier moet sprake zijn van een lijn van beoordelingen die op niveau 4 uitkomt en ook moeten meerdere stafleden zich aan de bekwaambeslissing committeren. Het onderdeel van het portfolio dat aantoont hoe de bekwaamverklaringen worden verkregen moet gemeenschappelijk bezit zijn van de aios én de opleider, dit in verband met mogelijke juridische consequenties.

In het gynaecologencurriculum HOOG is gekozen voor een combinatie van meer- dere gegevens op basis waarvan de opleidingsgroep besluiten neemt. Bij het bepalen van een standpunt over een bekwaamverklaring speelt de context (hoeveel backup biedt de omgeving?) een rol. Een bekwaam verklaarde aios moet dat inzicht ook hebben. Een nieuwe plek met een andere context vraagt er om dat de aios voorzichtig aftast of de bekwaamheid in de nieuwe situatie wel is waar te maken. Een echt bekwame aios herkent de risico's van de context en roept supervisie in. Dat brengt het belang van de algemene competenties in beeld. Het beeld van het functioneren op het terrein van de algemene competenties communicatie, samenwerking, organisatie en professioneel gedrag moet voldoende positief zijn om veilig een aios meer zelfstandigheid te geven. De aios moet de eigen grenzen herkennen en er moet voldoende interactie met de omgeving zijn, wil de aios in staat zijn goed zelfstandig te functioneren. Ook om deze reden volstaat hiervoor een beperkt aantal korte praktijkbeoordelingen niet.

Bij het toekennen van bekwaamverklaringen speelt het algemene beeld van het functioneren van de betreffende aios een rol. Een aios die al op meerdere terreinen in staat bleek veilig zelfstandig te bepalen waar supervisie te vragen en waar niet, en die op die terreinen in staat blijkt de algemene competenties goed in te zetten, zal een beperktere en meer gerichte bewijslast nodig hebben voor een volgende bekwaamverklaring. Wanneer een aios binnen een thema diverse taken zelfstandig mag uitvoeren zal dit een uitstralend effect krijgen op de zelfstandigheid die binnen het hele thema toegekend wordt.

Bij de feitelijke bekwaamverklaring is het aan te bevelen twee andere stafleden te betrekken die mede de verklaring tekenen, op grond van hun eigen observatie en oordeel. Hun commitment vergroot de kwaliteit van de beslissingen. Werken met 
gecommitteerde beoordelaars die hun oordeel niet rechtstreeks aan de aios maar aan de opleider kenbaar maken, biedt de opleider houvast in situaties waarin er druk kan bestaan vanuit de aios tot het afgeven van een bekwaamverklaring, terwijl de grond daarvoor nog te zwak is. Te denken valt aan de plaatsvervangende opleider en een inhoudelijk sterk betrokken lid van het opleidingsteam.

\section{Geldigheidsduur en universaliteit van een bekwaamverklaring}

Nadat een bekwaamheid bereikt is kan deze weer wegebben door onvoldoende expositie aan de betreffende professionele activiteit en door onvoldoende scholing over de betreffende activiteit. De KNMG heeft een accreditatiesysteem in het leven geroepen dat eisen voor herregistratie als medisch specialist regelt. Parameters in dit systeem zijn de bovengenoemde expositie aan de praktijk en bijscholing. Deze regeling wordt binnen de diverse disciplines verder verfijnd. Mogelijk zal in de toekomst gedifferentieerder worden hergeregistreerd binnen thema's (vakinhoudelijke domeinen binnen het specialisme). De herregistratieparameters zouden dan aangevuld kunnen worden met externe beoordelingen van de geleverde kwaliteit van zorg op die terreinen. De specialist houdt dan een portfolio bij waarmee bekwaamheid in een aantal thema's steeds opnieuw is aan te tonen.

Het lijkt aantrekkelijk en veilig om een bekwaamverklaring alleen binnen de bekende context van een bepaald opleidingsinstituut te laten gelden. Dit is echter niet realistisch omdat bij de afronding van een specialistenopleiding in een Nederlands opleidingsinstituut voor heel Nederland (en de E.U.) een brevet van vermogen binnen het betreffende specialisme wordt afgegeven. De specialist dient derhalve zelf rekening te houden met de verande- rende context en zich af te vragen of de bekwaamheid in een nieuwe context nog steeds opgaat. Het ligt in de rede met de bekwaamverklaring in de opleiding op dezelfde manier om te gaan. Hoewel bekwaamverklaringen bij de opleider geregistreerd staan en de aios bij een sollicitatie hiervan blijk kan geven in een portfolio, lijkt formele herregistratie voor afzonderlijke bekwaamverklaringen vooralsnog niet aangewezen en niet nodig. Regelmatige reflectie op de ontwikkeling van eerder bereikte bekwaamheid is te vereisen professioneel gedrag. In deze Richtlijn worden bekwaamverklaringen beschouwd als een opleidingsinstrument.

\section{Stadia in het traject van onbe- kwaam naar verklaard bekwaam}

Onbekwaam en bekwaam vormen geen dichotomie. Carraccio et al. hebben een beschrijving gegeven van de geleidelijke toename van expertise in de medische specialistische opleiding volgens de stadia uit het bekende model van Dreyfus \& Dreyfus zoals hierboven al is aangehaald. 2425 Er ontbreekt hier echter nog een relatie met formele bekwaamheid. De vertaling van dergelijke stadia naar bekwaamheid op de werkvloer is het best weer te geven in de mate waarin supervisie nodig wordt geacht c.q. moet worden verleend. In navolging van de vijf supervisieniveaus die vermeld zijn in het opleidingsplan Gynaecologie/Obstetrie HOOG $^{30}$ en in Ten Cate \& Scheele ${ }^{2}$ kunnen de bekwaamheidsniveau en bijbehorende supervisieniveaus als volgt worden gedefinieerd.

\section{Niveau I}

De aios heeft kennis van procedures en pathologie, maar wordt niet in staat geacht professionele activiteiten uit te voeren. Een aios met een bekwaamheid op niveau I heeft geen toestemming om een activiteit uit te voeren en heeft om die 
reden geen supervisie nodig met betrekking tot de betreffende activiteit.

\section{Niveau II}

De aios heeft voldoende kennis en vaardigheid, al of niet verworven met simulatiemethoden, om onder strenge supervisie een professionele activiteit uit te voeren. De aios is een 'novice' of 'leerling'. Er moet in dit stadium sprake zijn van zogeheten proactieve supervisie. Dat wil zeggen dat de supervisie niet alleen voortdurend aanwezig is, maar ook dat deze geïnitieerd wordt door en onder controle is van de supervisor.

\section{Niveau III}

In niveau III wordt de aios een professionele activiteit toevertrouwd in die zin dat hij of zij met beperkte supervisie zelfstandig kan werken. Deze supervisie kan worden aangeduid als reactieve supervisie. De aios vraagt om supervisie op het moment dat het nodig is; de supervisie moet echter direct, bij voorkeur binnen enkele minuten, beschikbaar zijn, bijvoorkeur fysiek, of - als dat verantwoord is - in eerste aanleg per telefoon. De aios die zich ten aanzien van een activiteit op niveau III bevindt kan worden aangeduid als 'advanced beginner' of 'gevorderd'.

\section{Niveau IV}

De aios op niveau IV wordt een professionele activiteit zonder supervisie toevertrouwd. 'Zonder supervisie' wil niet zeggen dat er geen supervisor is. Er is echter geen beschikbaarheid binnen enkele minuten. De supervisor draagt wel eindverantwoordelijkheid, maar kan, op grond van de bekwaamheid van de aios erop vertrouwen dat de activiteiten in beginsel correct zullen worden uitgevoerd. Op dit niveau kan de aios worden aangeduid als 'competent' of 'bekwaam'. Dit is een belangrijk stadium, omdat dit het niveau weerspiegelt dat de aios zelfstandigheid verwerft. Indien alle relevante professionele activiteiten minimaal op dit niveau kunnen worden toevertrouwd is in feite hiermee het eindniveau van de opleiding gedefinieerd. De verklaring van bekwaamheid voor een professionele activiteit is daarom aan dit niveau gekoppeld.

\section{Niveau $V$}

Het niveau van 'competent' is niet een eindniveau. De aios kan een niveau V bereiken, en daarmee aangeduid worden als 'proficient' of 'bedreven'. Dat niveau is nodig om supervisie te kunnen geven aan de aios op niveau II of III.

Aan dit stelsel kan nog een niveau VI worden toegevoegd, dat echter niet in het kader van de opleiding wordt bereikt. Dat is het niveau van het staflid met vele jaren ervaring in het vak en met de opleiding van aios. In het Dreyfus/Carraccio model zou de professional die dit heeft bereikt als 'master' of 'meester' moeten worden aangeduid.

\section{Weerstanden tegen de bekwaam- verklaring}

Vanuit het perspectief van zowel de opleider als de aios zijn weerstanden tegen bekwaamverklaringen te begrijpen. Vanuit het perspectief van de opleider is een bekwaamverklaring een vorm van 'de nek uit steken’. Waarom zou de opleider zo expliciet met deze moeilijke vraagstukken omgaan waar het tot nu toe impliciet in grote lijn redelijk verliep? Het is een verandering die tegemoet komt aan een om transparantie vragende maatschappij. Menig opleider lijkt er vooral een moeilijke en bureaucratische opdracht in te herkennen en voelt zich ook juridisch onzeker. Een bekwaamverklaring blijft een menselijke inschatting. Bovendien is een bekwaamverklaring een simplificatie 
van de complexe werkelijkheid, en zoals eerder vermeld afhankelijk van de context en van een aios die steeds weer in staat is de grenzen te herkennen. Wanneer de opleider ook na de opleiding enkele jaren medeverantwoordelijk zou blijven voor het functioneren voor de in diens centrum opgeleide aios, zou een stapsgewijze bekwaamverklaring veel logischer ervaren worden. De finale bekwaamverklaring aan het einde van de opleiding (het tekenen van het C-formulier van de MSRC) brengt geen relevant juridisch risico met zich mee. Waarom dan nu wel de nek uitsteken? Vanuit het perspectief van de aios is het enerzijds een blijk van erkenning en waardering, maar anderzijds een confrontatie met grote verantwoordelijkheid. De stappen in de verantwoordelijkheid moeten gepast zijn. Anders zou er een onveilig klimaat rond het functioneren van de aios kunnen ontstaan. Dit potentiële risico leidt tot drempelvrees bij diverse aios.

De mogelijke bezwaren van extra tijdsbeslag en toename van administratieve handelingen ten gevolge van de introductie van bekwaamverklaringen kunnen grotendeels worden weggenomen door de bekwaamverklaringen te verlenen op basis van de tijdens de opleidingsgesprekken door de aios te overleggen gegevens, verzameld in het portfolio waaronder het logboek met ervaringen, KPB's, OSATS en materialen die een beeld geven van het functioneren in contact met patiënten en met de organisatie. De bekwaamverklaringen zijn toe te voegen aan het digitale portfolio.

\section{Wat betekent een bekwaam- verklaring vanuit juridisch perspectief en welke voorwaarden zijn van vitaal belang?}

Wettelijk gezien is een aios zelfstandig bevoegd tot het uitvoeren van geneeskundige handelingen onder de voorwaarde dat hij tevens bekwaam is om de handeling uit te voeren. De wet BIG maakt onderscheid tussen deskundigheid (kennen), bekwaamheid (kunnen) en bevoegdheid. Onbekwaam maakt volgens de wet BIG onbevoegd en dus strafbaar. De beoordeling van de bekwaamheid laat de Wet BIG aan betrokkenen zelf over.

Bekwaamheid heeft betrekking op wat een beroepsbeoefenaar individueel weet én kan, het vermogen van een beroepsbeoefenaar om in een bepaalde situatie verantwoord een handeling uit te kunnen voeren. Of iemand daadwerkelijk bekwaam is, hangt dus af van individuele omstandigheden en van de aard van de zorgsetting. De daadwerkelijke bekwaamheid, en niet alleen het gevolgd hebben van een opleiding, bepaalt of iemand bevoegd kan handelen.

Eén van de voorwaarden die de Wet BIG aan de opleider stelt, is dat hij zich ervan moet vergewissen dat de aios bekwaam is om een handeling naar behoren uit te voeren. De opleider kan dit persoonlijk vaststellen of afgaan op het oordeel van een collega. Omdat in de dagelijkse praktijk een aios met verschillende supervisoren werkt is een sluitend systeem van bekwaamverklaringen een nuttig hulpmiddel. De bekwaamheid van een aios om bepaalde handelingen naar behoren uit te voeren, wordt schriftelijk vastgelegd in bekwaamheidverklaringen. Deze verklaring geeft aan dat de beroepsbeoefenaar theoretisch en praktisch geschoold is om de desbetreffende handelingen verantwoord uit te voeren op niveau 4.

Vanzelfsprekend moet de aios elke keer weer zelf bepalen of hij daadwerkelijk bekwaam is om een bepaalde behandeling uit te voeren. Ook is het van belang om de eenmaal verworven bekwaamheid regelmatig opnieuw te toetsen; dit om te voorkomen dat de bekwaamverklaring zijn waarde verliest. 
Het is niet zo dat een aios met een bekwaamverklaring in grotere mate aansprakelijk is voor eventuele schadelijke gevolgen van zijn handelen dan een aios zonder bekwaamverklaring. Of een dergelijke aansprakelijkheid bestaat, hangt in de eerste plaats af van de manier waarop de handeling is uitgevoerd.

Een lokaal protocol van bekwaamverklaring moet vooral de veiligheid van de aios en de patiënt in redelijkheid garanderen. Bij het opstellen van een lokaal protocol voor bekwaamverklaring speelt de werkomgeving een essentiële rol. De werkomgeving moet aan enkele voorwaarden voldoen om veiligheid te garanderen.

\section{Portfolio}

Het portfolio moet zodanig worden gehanteerd dat de aios en de opleider kunnen beargumenteren waarom de aios toe is aan een bepaalde mate van zelfstandigheid. Dat gaat over een combinatie van gegevens ${ }^{31}$ : over de hoeveelheid ervaring die de aios heeft, ${ }^{32}$ maar ook over toetsing van kennis en vaardigheden ${ }^{33}$ en over het vaststellen van een juiste attitude van de aios. ${ }^{34}$ De inschatting van de eigen grenzen door de aios is bij die attitude natuurlijk van evident belang.

\section{Vetorecht van twee kanten}

Een bekwaamverklaring moet in samenspraak tussen aios en opleider tot stand komen. Beiden hebben een vetorecht. Een aios moet zelf toe zijn aan die zelfstandigheid en de opleider, die medeverantwoordelijk blijft voor het functioneren van de aios, moet een zorgvuldige en veilige afweging gemaakt hebben. Het moet zowel voor de aios als voor de opleider 'goed voelen'.

\section{Veilig klimaat}

Het systeem van bekwaamverklaring vereist een veilig opleidingsklimaat. Dat betekent dat de aios een staflid te allen tijde ter supervisie kan vragen, ongeacht of er al formele eigen bekwaamheid geldt. De supervisor behoort dan te komen. Wordt die regel geschonden, dan wordt dit hoog opgevat en is de opleider verantwoordelijk voor een herstel van vertrouwen. Ieder staflid en iedere aios kent het concept van gedeelde verantwoordelijkheid.

\section{Blijvende bekwaamheid vergt toepassing} De aios die bekwaam verklaard is voor een verrichting behoudt deze status zolang de bekwaamheid tenminste op dit niveau gehandhaafd blijft. Dat vergt de gelegenheid tot regelmatige toepassing, en waar mogelijk de ontwikkeling van vaardigheid als supervisor van deze verrichting bij anderen. De opleider ziet erop toe dat deze bekwaamheidshandhaving geborgd is.

\section{Wat is de relatie van bekwaam- verklaringen met tempo en duur van de opleiding?}

Bij de snelheid waarmee een volledige bekwaamverklaring wordt bereikt zijn vier groepen van factoren van belang. ${ }^{1-2}$

- De verrichting zelf: Een complexe en riskante klinische taak past bij een langdurig leertraject en de leercurve zal dan trager zijn. Voor een klinische taak die vaker voorkomt zal de snelheid van de leercurve hoger zijn dan bij een zeldzamere taak.

- De werkomgeving: Waar in de kliniek een bekwaamverklaring voor een bepaalde taak heel handig is voor de bedrijfsvoering, wanneer het backup systeem voor het falen van de aios goed is opgezet en wanneer een curriculum eist dat er al in de eerste jaren zelfstan- 
digheid vereist wordt voor een bepaalde taak, zal de leercurve steil zijn.

- De aios zelf: Een begaafde aios met een hoge graad van motivatie en voldoende zelfvertrouwen kan steile leercurven tegemoet zien; ook de aios die de eigen grenzen goed kent en het vermogen heeft op risico's te anticiperen, zal sneller bekwaam verklaard kunnen worden.

- De opleider en diens team: Wanneer de opleider/supervisor 1) zelf goed vertrouwd is met de klinische taak, 2) aan de ontwikkeling van de aios aangepaste supervisie verschaft zodat de aios de gelegenheid krijgt vroeg nieuwe vaardigheden te verwerven, 3 ) goed in staat is de aios te toetsen op bekwaamheid en 4) vervolgens ook tot uitspraak van bekwaamheid wil over gaan, is een steilere formele leercurve te verwachten.

\section{Is er ervaring met dit model elders?}

Op de website van het Royal College of Obstetricians en Gynaecologist (www. rcog.org.uk $\rightarrow$ Education and Exams $\rightarrow$ Curriculum $\rightarrow$ Core) is gedetailleerd informatie te vinden over de opleiding tot gynaecoloog in de UK. De opleiding is in 19 hoofdstukken verdeeld (Core Modules) en de beoordelingen worden gedaan met het gebruik van OSATS en Mini-Cex (KPB) waarbij ook wordt aangegeven of de aios competent wordt geacht om een bepaalde behandeling zonder supervisie uit te voeren. (www.rcog.org.uk/education-andexams/curriculum/core). Er zijn met het werken met EPA's en bekwaamverklaringen recent eerste ervaringen opgedaan in een Physician Assistant opleiding. Hiervoor hebben opleiders een korte training gevolgd. ${ }^{35}$

\section{Literatuur}

1. Dijksterhuis MGK, Voorhuis M, Teunissen PW, Schuwirth LWT, ten Cate OTJ, Braat DDM, Scheele F. Assessment of competence and progressive independence in postgraduate clinical training. Med Educ 2009;42:1156-65.

2. Ten Cate O, Scheele F. Competency-Based Postgraduate Training: Can We Bridge the Gap between Theory and Clinical Practice? Acad Med 2007;82:542-7.

3. Teunissen PW, Scheele F, Scherpbier AJ, van der Vleuten CP, Boor K, van Luijk SJ, et al. How residents learn: qualitative evidence for the pivotal role of clinical activities. Med Educ 2007 Aug;41(8):763-70.

4. Seabrook M. Learning to teach. Postgrad Med J 2001 June;77(908):361-2.

5. Kennedy TJ, Regehr G, Baker GR, Lingard LA. Progressive independence in clinical training: a tradition worth defending? Acad Med 2005 Oct;80(10 Suppl):S106-11.

6. Dornan T. Osler, Flexner, apprenticeship and 'the new medical education'. J R Soc Med 2005 Mar; 98(3):91-5.

7. James M, Mears J, Draycott T. Training and education what is in it for the trainees. The Obstetrician \& Gynaecologist 2003;5:107-11.

8. Evans J, Goldacre MJ, Lambert TW. Views of junior doctors on the specialist registrar $(\mathrm{SpR})$ training scheme: qualitative study of UK medical graduates. Med Educ 2002 Dec;36(12):1122-30.

9. College of Physicians and Surgeons of Ontario. Professional Responsibilities in Postgraduate Medical Education, 2003.

10. Association of American Medical Colleges. AAMC Policy Guidance on Graduate Medical Education: Assuring Quality Patient Care and Quality Education. October 2001.

11. Kirk LM, Blank LL. Professional behavior - a learner's permit for licensure. The New England journal of medicine. 2005 Dec 22;353(25):270911.

12. Irvine DH. Everyone is entitled to a good doctor. The Medical journal of Australia. 2007 Mar 5; 186(5):256-61.

13. Ten Cate O. Entrustability of professional activities and competency-based training. Med Educ 2005:1176-7.

14. Ten Cate O. Trust, competence and the supervisor's role in postgraduate training. BMJ 2006;333: 748-751.

15. Vermunt JD, Verloop N. Congruence and friction between learning and teaching. Learning and Instruction. 1999;9:257-80.

16. Ten Cate O, Snell L, Mann K, Vermunt J. Orienting Teaching Toward the Learning Process. Acad Med 2004;79(3):219-28. 
17. Bandura A. Social Learning Theory. New York: General Learning Press 1977.

18. Wilkie G, Raffaelli D. In the deep and: making the transition from SpR to consultant. Advances in Psychiatric Treatment 11. 2005.

19. Higgins R, Gallen D, Whiteman S. Meeting the non-clinical education and training needs of new consultants. Postgrad Med J 2005 Aug;81(958): 519-23.

20. Bridges W. Managing Transitions. London: Nicholas Brealey Publishing;1998.

21. Sugarman L. Life-Span Development. London: Routledge; 1993.

22. Holmes TH, Rahe RH. The social readjustment rating scale. J Psychosom Res 1967;11(2):213-8.

23. Carraccio C, Wolfsthal SD, Englander R, Ferentz $\mathrm{K}$, Martin C. Shifting paradigms: from Flexner to competencies. Acad Med 2002;77:361-367.

24. Carraccio CL, Bradley MA, Benson J, Nixon LJ, MD, Derstine PL From the Educational Bench to the Clinical Bedside: Translating the Dreyfus Developmental Model to the Learning of Clinical Skills. Acad Med 2008;83:761-767.

25. Dreyfus HL, Dreyfus SE. Mind Over Machine. New York, NY: Free Press; 1988.

26. Willett LL, Heudebert GR, Palonen KP, Stanford Massie F, Kiefe CI, Allison JJ, Richman J, Houston TK. The Importance of Measuring Competency-Based Outcomes: Standard Evaluation Measures Are Not Surrogates for Clinical Performance of Internal Medicine Residents. Teaching and Learning in Medicine 2009;21(2):87093.

27. Lurie SJ Mooney CJ, Lyness JM. Measurement of the General Competencies of the Accreditation Council for Graduate Medical Education: A Systematic Review Acad Med 2009;84:301-309.

28. Epstein RM. Assessment in medical education. New Engl J Med 2007;356:387-96.

29. Miller GE. The assessment of clinical skills/ competence/performance. Acad Med 1990;65 (9 Suppl):63-7.

30. Scheele F en Schutte MF red. Curriculum opleiding tot gynaecoloog NVOG-HOOG. 2005. NVOG, Utrecht.
31. Van der Vleuten CPM en Schuwirth LWT. Assessing professional competence: from methods to programmes. Med Educ 2005;39:309-317.

32. Fok WY, Chan, LYS, Chung TKH. The effect of learning curve on the outcome of caesarean section BJOG 2006;113;1259-63.

33. Schuwirth LWT, Southgate L, Page GG, Paget NS, Lescop JMJ, Lew SR, Wade WB, Barón-Maldonado $\mathrm{M}$. When enough is enough: a conceptual basis for fair and defensible practice performance assessment. Med Educ 2002;36:895-997.

34. Scheele, F. Teunissen PW, Van Luijk SJ, Heineman E, Fluit L, Mulder H, Meininger A, WijnenMeijer M, Glas G, Sluiter H, Hummel T. Introducing competency-based postgraduate medical education in the Netherlands. Med Teach 2007;30:248-53.

35. Mulder H, Ten Cate O, Daalder R, Berkvens J. Building a competency-based workplace curriculum around entrustable professional activities: the case of physician assistant training (in voorbereiding).

De auteurs:

Dr. J.P. Lips is gynaecoloog en opleider in het Kennemer Gasthuis in Haarlem.

Prof. dr. F. Scheele is gynaecoloog en opleider in het Sint Lucas Andreas ziekenhuis in Amsterdam.

Drs. M.G.K. Dijksterhuis is gynaecoloog en plaatsvervangend opleider in het Ikazia ziekenhuis in Rotterdam. Drs. $M$ Westerman is onderwijscoördinator in het Sint Lucas Andreas ziekenhuis in Amsterdam.

Prof. dr. Th.J. ten Cate is hoogleraar medische onderwijskunde en directeur Expertisecentrum voor Onderwijs en Opleiding van het UMC Utrecht.

Correspondentieadres:

Dr. J.P. Lips, Kennemer Gasthuis, postbus 417, 2000 AK

Haarlem.E-mail: jlips@kg.nl

Belangenconflict: geen gemeld

Financiële ondersteuning: geen gemeld 